증 례

\title{
이산화질소 $\left(\mathrm{NO}_{2}\right)$ 에 의한 폐손상 치험 2예
}

경북대학교 의과대학 내과학교실

김연재 - 김성호-김수동-차승익
이 영 석 - 박 재 용 - 정 태 훈

$=$ Abstract $=$

Two Cases of Acute Lung Injury Caused by Nitrogen Dioxide Inhalation

Yeon Jae Kim, M.D., Seong Ho Kim, M.D., Su Dong Kim, M.D., Seung Ick Cha, M.D.

Yeung Suk Lee, M.D., Jae Yong Park, M.D. and Tae Hoon Jung, M.D.

Department of Internal Medicine, School of Medicine

Kyungpook National University, Taegu, Korea

\begin{abstract}
Human lung injury caused by the inhalation of nitrogen dioxide $\left(\mathrm{NO}_{2}\right)$ has been reported in occupational situations other than agriculture, including arc welding, production of nitric acid or explosives, and blasting operations. Nitrogen dioxide reacts with the water in the respiratory tract to form nitric acid. The nitrates and nitrites formed from dissociation of nitric acid cause extensive local and systemic tissue damage.

We present two cases of acute lung injury due to accidental inhalation of $\mathrm{NO}_{2}$ gas in occupational situtions with a review of the literature.
\end{abstract}

Key Words: Nitrogen dioxide, Lung injury

\section{서 론}

이산화질소(Nitrogen Dioxide, $\mathrm{NO}_{2}$ ) 는 식물의 발효 과정 및 산업장의 작업공정중1,2)에 생길 수 있으며 이의 흡입은 경미한 호흡기증상에서부터 폐부종, 폐쇄성세기 관지염 (bronchiolitis obliterans) ${ }^{3,4)}$ 까지 다양한 폐손상 을 초래할 수 있다. 1956년 이산화질소가 사일로-필러 병 (silo-filler's disease) 의 원인물질이라는 것이 밝혀 진(5) 이후 현재까지 약 90 여례가 보고 ${ }^{6,7)}$ 되고 있으나 우 리나라에서는 사일로 필러병에 대한 증례보고는 없고 산 업장에서 이산화질소의 흡입으로 인해 급성 폐부종이 발 생한 1 예가 보고되었었다 ${ }^{8)}$. 급속한 산업발전 및 대기오 염 등으로 이산화질소에 노출될 위험이 증가함에 따라 향후 이로 인한 폐손상도 적지 않을 것으로 생각된다.

저자들은 화학약품제조공장에서 누출된 이산화질소를
수분간 홉입후 기침 및 호흡곤란을 주소로 내원한 환자 2 예를 치험하였기에 문헌고찰과 함께 보고하는 바이다.

증 례

\section{증 례 1}

환 자 : 임 $\bigcirc$, 남자, 58세.

주 소 : 호흡곤란을 동반한 건성기침.

현병력 : 평소 건강하였으나 1992년 11월 21일 작업장 에서 동료 3 명과 함께 냉각이 제대로 되지 않은 누출된 황색의 이산화질소를 약 10 분정도 흡입후 현훈, 오심, 호흡곤란 및 심한 건성기침이 발생하여 인근병원에서 응 급처치후 본원으로 전원되었다.

과거력 및 가족력 : 특기사항 없음.

개인력 : 화학약품제조공장에 근무하고, 흡연력은 하 루 1갑씩 40년이었음. 
이학적 소견 : 급성 병색이었고 의식은 명료하였으며 혈압 $120 / 70 \mathrm{mmHg}$, 체온 $36.2^{\circ} \mathrm{C}$, 맥박은 분당 108 회, 그리고 호흡수는 분당 35 회였다. 폐청진시 양측 폐야에 흡기시 수포음이 들렸으며 심음은 빠른 편이었으나 잡음 은 들리지 읺았다. 복부 및 신경학적검사는 정상이었으 며 청색증은 없었다.

검사실 소견: 말초혈액검사상 혈색소 $18.2 \mathrm{~g} / \mathrm{dl}$, 적 혈구용적 $54.6 \%$, 백혈구 $19,600 / \mathrm{mm}^{3}$ (호중구 $91 \%$, 임파구 $7 \%$, 단핵구 $1 \%$ ) 이였으며 혈소판은 215,000/ $\mathrm{mm}^{3}$ 이었다. PT/PTT는 정상범위이었고 생화학적 검 사 및 대, 소변검사도 정상이었으며 혈중 메트헤모글로 빈은 $0.4 \%$ 이었다. 동맥혈가스검사상 $\mathrm{pH} 7.36, \mathrm{PaCO}_{2}$ $35 \mathrm{mmHg}, \mathrm{PaO}_{2} 78 \mathrm{mmHg}, \mathrm{HCO}_{3}^{-} 21.7 \mathrm{mEq} / \mathrm{L}$, $\mathrm{SaO}_{2} 91 \%$ 로 인근 병원에서 부신피질호르몬제재, 기관 지확장제의 정맥주사 및 산소흡입후 본원으로 전원된 상 태여서 심한 저산소혈증은 관찰되지 않았다. 흉부X-선 소견은 양측 전폐야에 미만성의 융합된 폐침윤이 관찰되 었으며 (Fig. 1-A), 흉부 고해상 전산화단층촬영은 양측 전폐야에 골고루 분포된 젖빛 유리모양 (ground glass appearance)의 폐경화소견이었다. 입원 3일째 실시한 폐기능검사는 표 1 과 같이 흡기의 불균등 폐내분포와 세 소기도 병변을 동반한 폐확산능의 심한 저하가 관찰되었
으며 심전도는 정상소견이었다.

치료 및 임상경과 : 경비관을 통한 $100 \%$ 산소흡입과 부신피질호르몬 및 광범위 항생제로 입원 4일경 폐청진 상 수포음이 없어졌으며 흉부 X-선사진(Fig. 1-B) 및 고해상전산화단층칠영상 폐침윤 소견도 신속하게 호전 되였다. 환자는 입원 11 일만에 건강한 상태로 퇴원하였 으며 외래에서 추적 실시한 폐기능검사상 흡기의 폐내분 포와 폐확산능의 뚜렷한 호전이 관찰되었다(Table 1).

Table 1. Changes of Pulmonary Function Tests

\begin{tabular}{lrrrr}
\hline \hline & \multicolumn{2}{c}{ Case 1 } & \multicolumn{2}{c}{ Case 2 } \\
\cline { 2 - 5 } Parameters & 3 days & 4 wks & 3 days & 4 wks \\
\hline FVC & 101 & 126 & 63 & 91 \\
FEV $_{1}$ & 91 & 109 & 63 & 94 \\
FEV $_{1} /$ FVC $\%$ & 85 & 83 & 95 & 99 \\
FEF25-75\% & 38 & 47 & 33 & 55 \\
CV/VC\% & 90 & 100 & 219 & 112 \\
$\Delta N_{2} / L$ & 392 & 162 & 700 & 100 \\
DLCO & 54 & 74 & 50 & 83 \\
DLCO/VA & 46 & 53 & 56 & 82 \\
\hline
\end{tabular}

Figures are expressed as a percentage of the predicted.

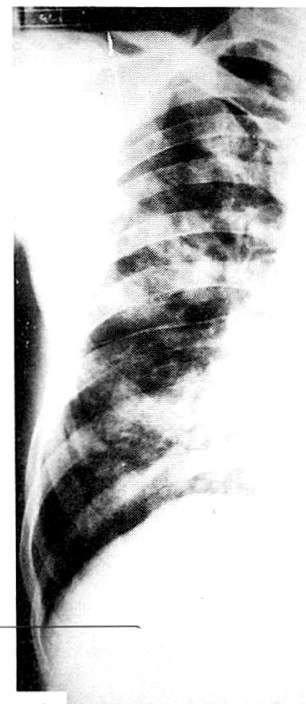

A
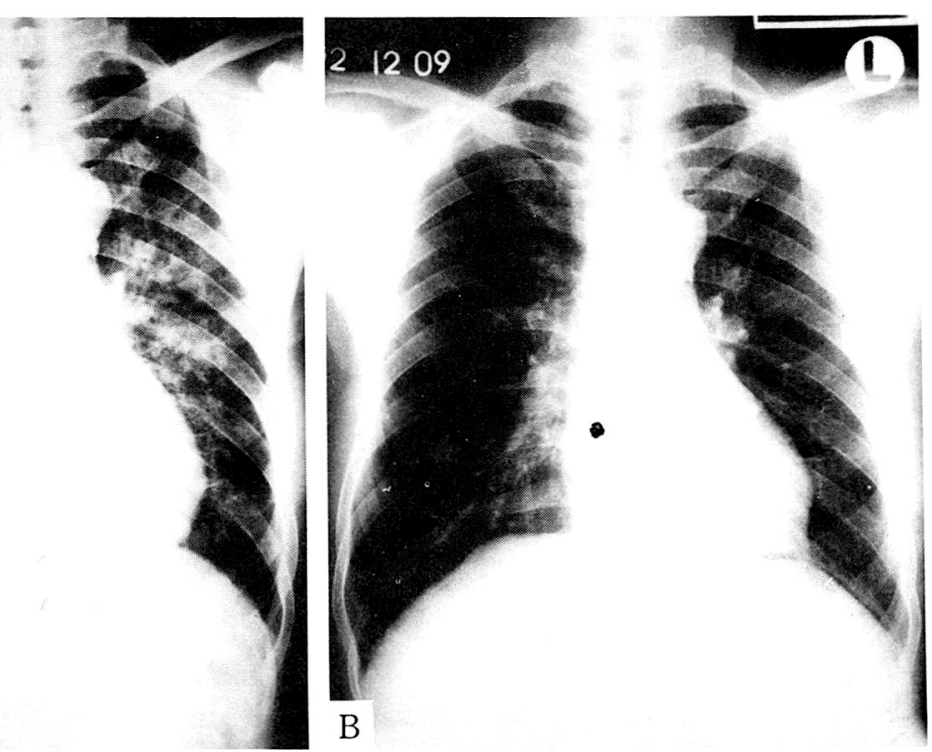

Fig. 1. Chest roentgenogram of case 1, A, diffuse bilateral perihilar radiating pulmonary infiltrates on admission, $\mathrm{B}$, complete resolution of lung infiltrates after treatment. 


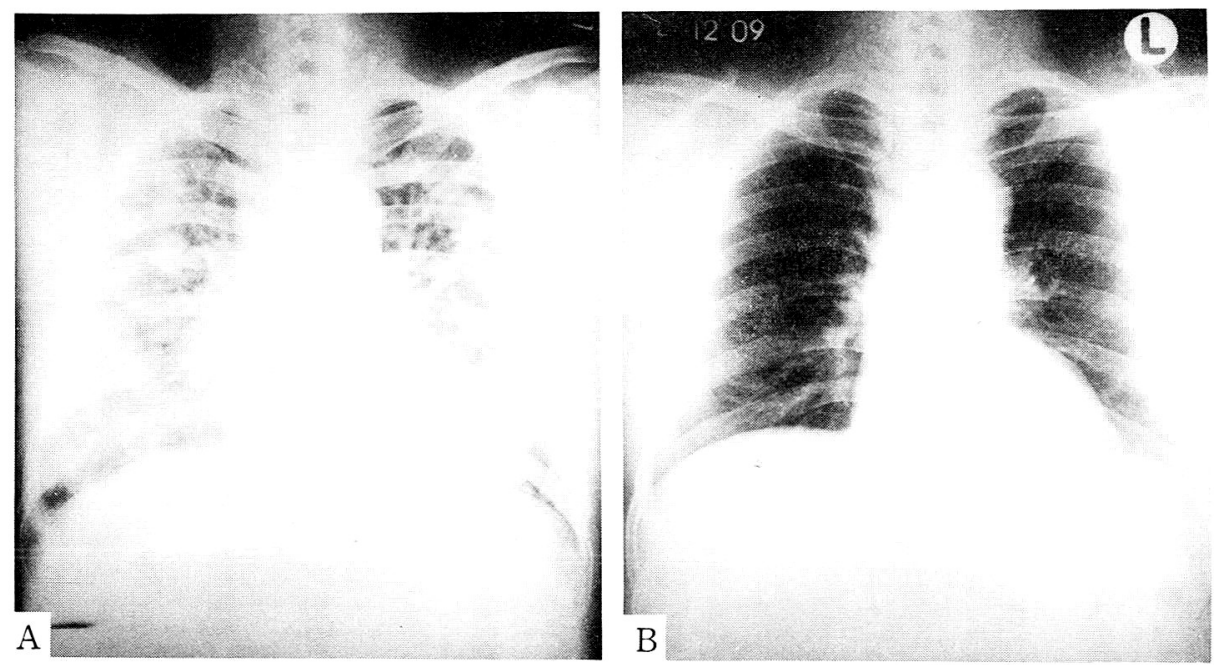

Fig. 2. Chest roentgenogram of case $2, \mathrm{~A}$, diffuse bilateral nodular or confluent infiltrates and cardiomegaly on admission, B, after treatment, complete resolution of lung lesions and slight reduced heart size.

\section{증 례 2}

환 자: 박 $\mathrm{O}$, 남자, 43 세.

주 소: 호흡곤란을 동반한 건성기침.

현병력 : 평소 건강하였으나 1992년 11월 21일 작업 장 에서 냉각이 제대로 되지 않은 누출된 황색의 이산화질 소를 약 10 분정도 흡입후 심한 건성기침 및 호흡곤란이 발생하여 인근병원에서 응급처치후 본원으로 전원되었 다.

과거력 및 가족력 : 특기사항 없음.

개인력 : 화학약품제조공장에 근무하고, 흡연력은 하 루 1갑씩 25년이었음.

이학적 소견 : 급성 병색이었고 의식은 명료하였으며 혈압 $140 / 70 \mathrm{mmHg}$, 체온 $36.0^{\circ} \mathrm{C}$, 맥박은 분당 65 회, 그리고 호흡수는 분당 30회였다. 폐청진시 양측 전폐야 에 흡기시 수포음이 들렸다. 심음은 정상이었고 복부 및 신경학적검사도 정상이었으며 청색증은 없었다.

검사실 소견 : 말초혈액검사상 혈색소 $19.1 \mathrm{~g} / \mathrm{dl}$, 적 혈구용적 $51.3 \%$, 백혈구 $23,000 / \mathrm{mm}^{3}$ (호중구 $93 \%$, 임파구 $5 \%$ ) 이었으며 혈소판은 $399,000 / \mathrm{mm}^{3}$ 이었다. $\mathrm{PT} / \mathrm{PTT}$ 는 정상범위이었고 생화학적 검사 및 대, 소변 검사도 정상이었으며 혈중 메트헤모글로빈은 $0.3 \%$ 이었 다. 동맥혈가스검사는 제 2표와 같이 $\mathrm{pH}$ 7.19, $\mathrm{PaO}_{2}$ $66.1 \mathrm{mmHg}, \mathrm{PaCO}_{2} 49 \mathrm{mmHg}, \mathrm{HCO}_{3}{ }^{-} 19.2 \mathrm{mEq} / \mathrm{L}$,
Table 2. Changes of Arterial Blood Gas Analysis in Case 2

\begin{tabular}{llccc}
\hline \hline Parameters & 도착당시 & 24시간후 & 48시간후 \\
\hline $\mathrm{PH}$ & & 7.19 & 7.26 & 7.40 \\
$\mathrm{PaO}_{2}$ & $\mathrm{mmHg}$ & 66.1 & 115.0 & 167.4 \\
$\mathrm{PCO}_{2}$ & $\mathrm{mmHg}$ & 49.0 & 39.7 & 37.0 \\
$\mathrm{HCO}_{3}^{-}$ & $\mathrm{mEq} / \mathrm{L}$ & 19.2 & 18.8 & 23.4 \\
$\mathrm{SaO}_{2}$ & $\%$ & 87.3 & 97.9 & 99.5 \\
\hline
\end{tabular}

$\mathrm{SaO}_{2}$ 87.3\%로 저산소혈증 및 혼합성산혈증 소견을 보 였다. 흉부X-선소견은 양측 전폐야에 미만성의 융합된 폐침윤과 심비대소견이었으며(Fig. 2-A) 흉부 고해상 전산화단층촬영은 양측 전폐야에 중심소엽성 (centrilobular) 또는 포상 (acinar) 형태의 젓빛유리모양의 폐경 화소견이었다(Fig. 3-A). 입원 3일째 실시한 폐기능검 사는 흡기의 불균등 폐내분포, 혼합성 환기장애 및 폐확 산능의 심한 저하가 관찰되었다(Table 1).

치료 및 임상경과 : 경비관을 통한 $100 \%$ 산소흡입과 부신피질호르몬 및 광범위 항생제로 입원 5 일경 폐청진 상 수포음이 없어졌으며 흥부X선사진 및 고해상전산화 단층찰역상 폐침윤소견도 신속하게 호전되었다(Fig. 2 -B,3-B). 그리고 동맥혈가스의 산혈증소견도 48시간후 정상으로 회복되었다(Table 2). 환자는 입원 11일만에 퇴원하였으며 외래에서 추적 실시한 폐기능검사는 

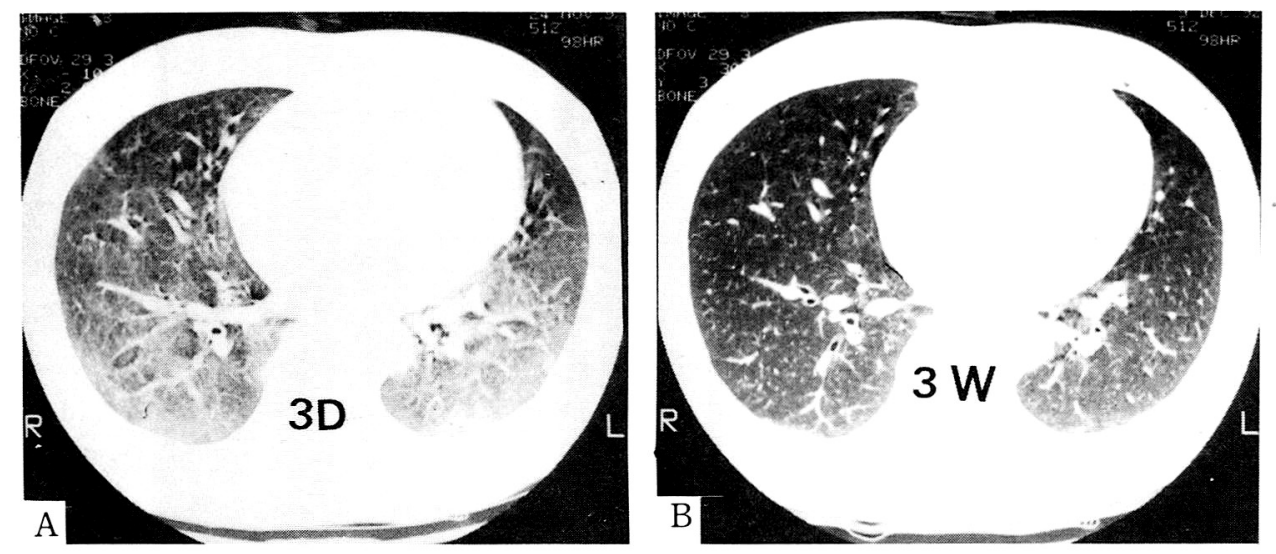

Fig. 3. High resolutional $\mathrm{C}_{-1}$ scan of middle lung field in case 2, A, diffuse bilateral groundglass opacity on 3 days of admission, B, marked improvement of lung lesions after 3 weeks.

Table 1 과 같이 흡기의 폐내분포와 폐확산늑의 뚜렷한 호전이 관찰되었다.

\section{고}

찰

이산화질소로 인한 사망환자는 1804 년에 처음 보고되 었다9). 1914년에는 사일로내에서 갑자기 사망한 4예가 보고 ${ }^{10)}$ 되었고 1956 년에 처음으로 사일로-필러병 (silofiller's disease) 으로 기술회되면서부터 이산화질소가 본 증의 원인으로 밝혀졌다. 사일로내의 저장곡식에 함유 되어 있는 질산(nitrates)은 세균에 의해 일산화질소 $(\mathrm{NO})$ 로 전환되고, 이는 공기와 반응하여 이산화질소 $\left(\mathrm{NO}_{2}\right)$ 로 되며, 이 이산화질소는 dimer인 사산화질소 $\left(\mathrm{N}_{2} \mathrm{O}_{4}\right)$ 와 동시에 존재하여 급성 폐손상을 유발할 수 있 다 ${ }^{1)}$. 보통 사일로내에서 이산화질소는 즉시 형성되어 1 2일내 200 2000 ppm의 최고농도에 달하게 되며 환 기가 안되고 완전히 폐쇄된 사일로내에서는 수 주 동안 유해농도를 유지한다고 한다6). 이산화질소의 흡입으로 인한 폐손상은 이러한 농업분야 뿐만 아니라 전기용접, 화약제조, 발파작업 등의 산업장에서도 보고 ${ }^{2,3,8)}$ 되고 있 으며, 플라스틱, 구두약, 셀룰로오드 등의 연소시에도 유해량의 이산화질소가 발생한다고 한다 ${ }^{3.11}$. 본 증례들 은 화학약품제조공장에서 작업하다가 냉각이 되지 않은 누출된 이산화질소가스를 수분간 흡입하였다.

이산화질소는 강력한 산화제로써 산소기를 유리할 수 있으며 수용액에서는 질산 및 아질산으로 되어 호흡기계
조직의 단백질과 반응한다 ${ }^{12)}$. 주로 종말세기관지를 포 함한 conducting airway에 작용을 하여 일시적인 기관 지수축 및 상피세포에 손상을 일으켜 섬모의 소실을 초 래하며 또한 제 2형 폐포세포 및 혈관내피세포에도 작용 을 하여 tight capillary junction의 붕괴 및 폐부종을 초래하기도 하고 계면활성체기능도 변화시킨다고 한 다 ${ }^{13)}$. 흡입후 점막자극으로 인한 경미한 호흡기증상에 서부터 화학성 폐렴, 폐부종 심지어는 사망까지 할 수 있으나 호흡곤란 및 기침이 각각 $89,64 \%$ 로 가장 많은 증상이라고 하며 6,7$)$ 이는 흡입농도 및 노출시간에 비례 한다고 한다 ${ }^{11}$. 본 증례의 2 예를 포함하여 이번 사고로 생긴 4예 가운데 3예에서 노출 즉시 호흡곤란을 동반한 심한 건성기침이 발생하였으며 이가운데 1 예는 인근병 원에서 응급처치도중 사망하였으며 나머지 1 예에서는 증상을 호소하지 않았다.

이학적소견은 빈호흡이 가장 많고 폐청진시 수포음, 천명음, 호흡음의 감소 등을 관찰할 수 있으며 그 외에 결막충혈, 사지에 청색증 등이 올 수 있다6.7). 본 증례들 은 모두 빈호흡이 있었고 폐야에서 수포음이 청진되었 다. 검사실 소견상 말초혈액에 백혈구증가가 관찰될 수 있지만 증상의 정도 및 예후와는 관계없다고 한다 ${ }^{14}$. 폐 기능 소견은 동맥혈 저산소혈증6.7.14)과 폐확산능의 심한 저하가가 관찰되며 동맥혈 저산소혈증은 급성폐손상으로 인한 기도의 가역적 번화 및 폐부종 등으로 환기-관류비 의 불균형, 동-정맥 단락 그리고 질산이온이 혈색소와 반응하여 형성된 메트헤모글로빈혈증때문이라고 한 
다 ${ }^{15)}$. 본 증례가운데 첫 예는 동맥혈 저산소혈증은 관찰 되지 않았으나 이는 인근병원에서 처치한 고농도 산소 및 부신피질호르몬 효과때문일 것으로 추정되며 혈중 메 트헤모글로빈은 2예 모두에서 관찰되었다. 그리고 본 증 례들에서는 폐확산능의 심한 저하와 흡기의 불균등 폐내 분포경향을 나타내었는데 폐확산능의 저하는 폐부종으 로 인한 폐포 모세혈관막의 비후 및 폐포막액의 점성도 의 변화 때문일 것으로 생각되었고 기도의 가역적 변화 및 폐탄성의 감소로 인해 흡기시 팽창이 덜되어 환기의 불균등 분포를 나타낸다고 생각되었으며 이러한 폐기능 의 이상은 치료를 함으로써 정상으로 회복되었다. 그리 고 드물게 대사성 산혈증과 저혈압이 관찰될 수 있다고 한다 ${ }^{6.16)}$. 대사성 산혈증은 이산화질소가 체액에 용해되 어 질산 및 아질산을 형성하고 또한 조직내의 심한 저산 소증으로 인한 이차적 유산산증이 발생할 수 있기 때문 이며, 이들 이온들의 혈관확장작용으로 저혈압이 생긴 다고 한다 ${ }^{15,16)}$. 본 증례들에서는 저혈압은 관찰되지 않 았으나, 두번째 증례에서 대사성 산혈증이 동반되었으 며 부신피질 호르몬투여 및 고농도 산소흡입으로 약 48 시간후에 정상으로 회복되었다. 흉부X선사진은 폐부종 또는 기관지폐렴 소견이 나타날 수 있는데 본 증례들과 마찬가지로 대개 양측성으로 융합된 폐침윤이 특징적이 지만 침윤정도 및 양상은 증상의 정도나 예후와는 관계 없고 치료를 함으로써 신속하게 정상으로 호전된다고 한 다 ${ }^{14)}$. 증례들의 흉부 고해상전산화단층사진은 폐간질의 비후는 관찰되지 않고 양측성, 미만성의 중심소엽성 (centrilobular) 또는 포상 (acinar)형태의 젗빛유리모 양의 폐경화소견이었다. 이와 같은 방사선 사진소견과 이산화질소흡입의 병태생리로 봐서 본 증례들의 폐병변 은 주로 종말세기관지 및 세기관지주위의 폐포를 중심으 로 한 광범위한 기관지폐렴양상으로 나타났으며 이산화 질소가 폐포투과성을 변화시켜 ${ }^{17)}$ 비혈관성 폐부종도 어 느정도 동반되었을 것으로 생각되었다.

Tse 등1ㅣ은 이산화질소에 의해 화학성 폐렴, 폐부종 등과 같은 급성 폐손상에서 회복된 2 6주후에 다시 폐 병변이 재발할 수 있기 때문에 주의를 해야 한다고 하였 다. 즉 세기관지의 염증으로 인하여 폐쇄성세기관지염 (bronchiolitis obliterans)이 합병되기 때문이며, 이때 환자는 열, 기침, 호흡곤란 등을 호소하고 흉부X선 사 진상 미만성으로 망상결절성 또는 속립성의 폐침윤이 다 시 나타날 수 있다 ${ }^{2,3)}$. 이는 이산화질소의 노출병력이 확
실하지 않은 경우, 기관지 폐렴, 만성농부폐, 속립성 폐 결핵 또는 전이성 암과 감별이 요하며 진단은 대개 개훙 폐생검이 필요하당.

본 증의 치료는 환자의 임 상상태에 따라 달라진다. 급 성 폐손상이 있는 경우는 부신피질호르몬의 투여가 효과 적이며 ${ }^{6,8)}$, 산소흡입 및 저용량의 methylene blue 정맥 주사는 메트헤모글로빈혈증을 교정함으로써 동맥혈 저 산소혈증의 치료에 도움이 된다고 한다6). 그리고 심한 폐부종이 동반되면 강심제나 이뇨제의 투여는 효과가 없 고 고농도의 산소흡입 및 적절한 보조호흡으로 환기부전 상태를 교정해 주어야 한다. 또한 기도청소능의 유지 및 기도협착이나 감염의 소견이 있는 경우는 기관지확장제 나 항생제의 사용도 도움이 된다 ${ }^{14)}$. 부신피질호르몬제 재의 투여는 세기관지의 염증을 감소시켜 폐쇄성세기관 지염으로의 파급을 방지할 수 있기 때문에 Mayo Clinic 에서는 급성폐손상에서 회복후 경구용 부신피질호르몬 제재를 3 4주간 계속 투여하는 것을 권장하고 있으며 ${ }^{6}$ 폐쇄성세기관지염의 발생유무는 적어도 6 주동안은 관찰 이 필요하다. 본 증례들은 부신피질호르몬제재 (hydrocortisone)의 정맥주사 및 고농도의 산소흡입으로 증상 및 방사선 소견이 신속하게 호전되었으며 연속하여 경구 부신피질호르몬제재인 prednisone을 2주동안 투여하였 다. 현재 6 개월째 관찰중이나 폐쇄성세기관지염의 발생 증거는 없는 상태이다.

사일로-필러병의 사망율은 9 20\%라고 하며 6.7) 산업 장에서 이산화질소의 흡입으로 인한 사망율의 정확한 통 계는 없으나 대개 흡입농도 및 노출기간, 화학성 폐렴이 나 폐부종의 발생시기등이 예후와 관계가 있다고 한 다 ${ }^{11}$.

\section{요 약}

경북대학교병원 호흡기내과에서 1992년 10월 화학약 품제조공장에서 누출된 이산화질소의 흡입으로 인하여 급성폐손상을 받은 남자 2예를 치험하였기에 문헌고찰 과 함께 보고하였다.

\section{REFERENCES}

1) Grayson RR: Silage gas poisoning: nitrogen dioxide pneumonia, a new disease in agricultural workers. 
Ann Intern Med 45:393, 1956

2) Horvath EP, doPico GA, Barbee RA, Dickie HA: Nitrogen dioxide-induced pulmonary disease. $\mathrm{J}$ Occup Med 20:103, 1978

3) $\mathrm{M}_{\mathrm{C}} \mathrm{A}_{\text {DAMs }} \mathrm{AJ}$ : Broncholitis obliterans. Am J Med 19: 314, 1955

4) Moskowitz RL, Lyons HA, Cottle HR: Silo filler's disease: Clinical, physiologic and pathologic study of a patient. Am J Med 36:457, 1964

5) Delaney LT, Schmidt HW, Stroebel CF: Silo-filler's disease. Mayo Clin Proc 31:189, 1956

6) Douglas WW, Hepper NGG, Colby TV: Silo-filler's disease. Mayo Clin Proc 64:291, 1989

7) Zwemer FL, Pratt DS, May JJ: Silo filler's Disease in New York State. Am Rev Respir Dis 146:650, 1992

8) 정준표, 안철민, 신용운, 이강석, 김성규, 김기호 : 이산화질소(Nitrogen Dioxide: $\mathrm{NO}_{2}$ ) 홉입에 의한 급 성 폐부종 치험 1례. 대한내과학희 잡지 30:407, 1986

9) Ramirez-R J: The first death from nitrogen dioxide fumes: the story of a man and his dog. JAMA 229: 1181, 1974

10) Hayhurst ER, Scott E: Four cases of sudden death in a silo. JAMA 63:1570, 1914

11) Tse RL, Bockman AA: Nitrogen dioxide toxicity: report of four cases in fireman. JAMA 212:1342,
1970

12) Mustafa MG, Tierney DF: Biochemical and metabolic changes in the lung with oxygen, ozone, and nitrogen dioxide toxicity. Am Rev Respir Dis 118: 1061, 1978

13) Dowell AR, Kiburn KH, Pratt PC: Short term exposure to nitrogen dioxide: Effects on pulmonary ultrastructure, compliance, and the surfactant system. Arch Intern Med 128:74, 1971

14) Ramirez-R J, Dowell AR: Silo-filler's disease: Nitrogen dioxide-induced lung injury. Long-term followup and review of the literature. Ann Intern Med 74: 569, 1971

15) Greenbaum R, Bay J, Hargreaves MD: Effect of higher oxides of nitrogen on the anesthesized dog. Brit J Anesth 39:393, 1967

16) Prys-Roberts $C$ : Principles of treatment of poisoning by higher oxides of nitrogen. Brit J Anesth 39: 432, 1967

17) Rasmussen TR, Kjaergaard SK, Tarp U, Pedersen OF: Delayed effects of $\mathrm{NO}_{2}$ exposure on alveolar permeability and glutathione peroxidase in healthy humans. Am Rev Respir Dis 146:654, 1992 